\title{
Towards standardised crown condition assessment in poplar plantations
}

\author{
Jorge MARTín-GARCÍA ${ }^{1 *}$, Julio Javier DIEZ ${ }^{1}$, Hervé JACTEL ${ }^{2}$ \\ ${ }^{1}$ Department of Plant Production and Forest Resources, University of Valladolid, Avenida de Madrid 44, 34004 Palencia, Spain \\ ${ }^{2}$ Université de Bordeaux, INRA, UMR 1202 Biodiversity, Genes and Communities, 33612 Cestas Cedex, France
}

(Received 26 May 2008; accepted 20 December 2008)

\author{
Keywords: \\ poplar / \\ indicator / \\ forest health / \\ crown condition / \\ CROCO
}

\begin{abstract}
- This work aims at developing new tools for rapid assessment of forest health indicators in poplar plantations.

- Crown transparency and discoloration were visually evaluated in all trees of four 15 m-radius subplots in 32 poplar clonal plantations, which were chosen according to a factorial scheme with three factors: tree age, site quality and understorey vegetation management. A subset of trees was assessed using digital photos processed with a semi-automatic image analysis system (the CROCO software) in order to compare visual and digital crown transparency estimates.

- Poplar crown conditions were better in young stands and rich sites. Harrowing understorey vegetation improved tree health in poor sites. Samples of 20 trees per stand provided the same information about crown transparency and discoloration as 60 trees. Calibration curves of digital crown transparency estimates were successfully fitted against visual crown transparency estimates. The same effects of stand age and site quality could be detected with digital crown transparency as response variable.

- The use of digital photos processed with CROCO in ca. twenty trees per stand is therefore recommended to accurately and objectively monitor crown condition in clonal poplar plantations.
\end{abstract}

Résumé - Améliorations en vue d'un suivi standardisé de l'état sanitaire des houppiers en plantations monoclonales de peuplier.

- Une étude a été réalisée pour développer des méthodes rapides et standardisées de suivi de l'état sanitaire des houppiers en plantation de peuplier.

- La transparence et la décoloration des houppiers ont été estimées visuellement sur tous les arbres de quatre placettes d'un rayon fixe de $15 \mathrm{~m}$, dans 32 plantations monoclonales de peuplier choisies selon un plan factoriel complet croisant trois facteurs : l'âge des plantations, la fertilité du site et la gestion du sous-bois. La moyenne des notes de transparence et de décoloration des houppiers a été calculée sur un nombre décroissant de placettes par plantation afin de tester l'influence de la taille de l'échantillon sur la qualité de l'estimation. Des photographies numériques du houppier d'un souséchantillon de peupliers ont été également prises puis traitées à l'aide du logiciel CROCO afin de comparer les estimations visuelles et numériques de la transparence du houppier.

- L'état sanitaire des houppiers était meilleur dans les jeunes plantations de peupliers et les sites les plus fertiles. Le hersage de la végétation du sous-bois a permis d'améliorer l'état sanitaire des peupliers dans les sites les plus pauvres. Les valeurs moyenne de transparence et de décoloration du houppier par plantation, calculées à partir des données d'une seule placette de $15 \mathrm{~m}$ de rayon - soit une vingtaine d'arbres - ne différaient pas significativement de celles calculées à partir des données de trois placettes et permettaient de détecter les mêmes effets des caractéristiques du peuplement et du site. Des courbes de calibration de la transparence du houppier estimée à partir de photos numériques et du logiciel CROCO ont pu être ajustées aux observations de transparence. Les effets de l'âge des plantations, de la fertilité du site et de la gestion du sous-bois ont pu également être détectés avec ces valeurs numériques calculées.

- Il peut donc être recommandé d'utiliser des photos numériques traitées à l'aide du logiciel CROCO pour estimer la transparence du houppier d'une vingtaine d'arbres afin d'évaluer rapidement, précisément et objectivement l'état sanitaire des plantations monoclonales de peuplier.

\footnotetext{
* Corresponding author: jorgemg@pvs.uva.es
} 


\section{INTRODUCTION}

Since the United Nations Conference on the Environment and Development (UNCED, Rio de Janeiro, 1992), the sustainable forest development (SFM) has become an essential concept worldwide (Castañeda et al, 2001). To assess the implementation of SFM different criteria have been elaborated. For example, the Ministerial Conferences for the Protection of Forests in Europe (MCPFE) has proposed a set of six criteria that relate to key elements of sustainability. In particular the second criterion deals with the maintenance of forest ecosystems health and vitality. Because policy makers and forest managers require instruments to evaluate progress towards implementing sustainable forest management, quantitative and qualitative indicators have been developed for each criterion. A considerable effort has been paid to improve SFM indicators as they need to be accurate and reliable but also sufficiently straightforward and cost effective to be documented over time (Hunsaker, 1993). For example crown transparency and crown discoloration are often used as indicators of tree health and vitality (Zarnoch et al., 2004), because they comply with these desirable indicators characteristics.

A forest health monitoring program has been carried out in Europe since the 1980s within the International Co-operative Programme, ICP Forest (Level I European network). It comprised more than 6100 plots, where both tree crown transparency and crown discoloration were visually estimated on ca. 20 trees per plot each year. However, the ability of such a systematic network to capture the real health condition of small and fragmented forest types remains questionable (Ferretti, 1997). This is the case of poplar plantations, which cover about 800000 ha in Europe and yet there are only 23 plots of Populus monitored within the European Level I Network (Lorenz et al., 2005). It is therefore desirable to increase the number of sampled plots and one way to reach this objective for the same effort is to minimize the number of sampled trees per plot. Because poplar, willow or eucalyptus plantations are often monoclonal, protocols developed to assess health conditions in other types of forest may not be relevant. In particular, as the variability of traits between trees is lower, one can assume that tree clones will be similarly damaged (Braganca et al., 1998; Camps, 2001; Sierra, 2001) and that smaller samples of trees can be representative for the whole stand condition.

Another option to increase the reliability of forest health assessment while keeping the sampling effort to a minimum is to develop automatic, standardized methods. Considerable effort has been devoted to improve the assessment of tree crown transparency and discoloration (Ferretti, 1997). In the European Network Level I, these variables are visually estimated by observers from the ground, but due to the subjectivity of human assessment, data quality and comparability across countries have been questioned (Mizoue and Dobbertin, 2003). The sources of error in the quantitative assessment of crown condition are many, including variation in the expertise of observers, weather conditions, crown appearance, tree species, tree age and social position (Ghosh et al., 1995; Innes et al., 1993; Redfern and Boswell, 2004; Solberg and Strand, 1999; Wulff,
2002). Such sources of error make it difficult to compare patterns between countries, and even across time within the same country. They may also mask the relationship between forest decline and explanatory factors such as pest pressure or site conditions. Researchers have tried to solve these problems, combining field and control team assessments (Ghosh and Innes, 1995), using data from cross-calibration courses to estimate correction factors for between countries differences (Innes et al., 1993), using reference photographs (Solberg and Strand, 1999) or standard sets of two-dimensional silhouettes representing various degrees of foliage density (Frampton et al., 2001). Nevertheless, these improvements sometimes are not enough and proposals have been made to replace visual ground assessment by digital photo (Čermák et al., 2007; Mizoue, 2002; Sang-Mook et al., 2003) or by remote sensing techniques (Coops et al., 2004; Solberg et al., 2004; Stone et al., 2003). In particular, Mizoue (2002) developed a semiautomatic image analysis system, called CROCO, to assess crown transparency from digital photographs.

The main objective of this study was therefore to refine a monitoring method to assess two important forest health indicators in poplar stands quantitatively and objectively. To achieve this objective the following two questions were addressed:

1. Is a sample of 20 trees large enough to detect the effects of age, site and management on crown transparency and discoloration in poplar stands?

2. Can visual crown transparency be substituted by CROCO estimates to detect the same effects of site and management in poplar stands?

\section{MATERIALS AND METHODS}

\subsection{Site description and experimental design}

The present study was carried out in Castile and Leon (Spain) where there are about 45000 ha of poplar plantations, the most common species grown is Populus $\times$ euramericana hybrid $(P$. nigra $\times$ $P$. deltoides). Several clones are used, but the clone I-214, covering about $70 \%$ of the total poplar plantation area (Fernández and Hernanz, 2004), is the most representative. The density of trees in clonal poplar plantations is kept constant during the whole rotation, at about 278-400 stems/ha, according to the planting distance of $6 \times 6$ or $5 \times 5 \mathrm{~m}$, respectively. Traditional management of poplar stands is only applied during the first six years of the plantation: understorey vegetation is controlled with disc harrowing every year until canopy closure and all trees are pruned up to six meters from the ground level. Poplar plantations are clear-cut at fourteen years.

The experimental design consisted of a factorial scheme with three factors: (1) stand age (young stands of 3-7 years old or adult stands of 8-14 years old), (2) understorey management (harrowed or not harrowed) and (3) site quality. We differentiated rich sites (quality 1 and 2) or poor sites (quality 3 and 4), according to the site quality abacus developed for the Populus $x$ euramericana clone I-214 in the river Duero basin (Bravo et al., 1995). Four I-214 clonal plantations as replicates of each factors combination were sampled. A total of 32 poplar stands were therefore sampled in the north of the Palencia 
province, within the Carrion river basin (from 346405 to 366495 and 4686275 to 4712381 , latitude and longitude respectively in UTM coordinates).

\subsection{Assessment of crown condition variables in poplars}

In each stand, four circular subplots of $15 \mathrm{~m}$ radius were monitored. These subplots were located $50 \mathrm{~m}$ apart from each other, at the ends of cross located in the middle of the stand. Within each subplot all trees were marked and sampled. All sub-plots had the same number of sampled trees in a given stand ( 21 on average). A total of 2695 poplar trees were assessed during the summer of 2005 (within the first two weeks of July) as recommended in the ICP protocol. Crown transparency and discoloration were visually estimated and quantified using twenty classes of 5\% width, according to Level I European network methodology (Eichhorn et al., 2006). Simultaneously, all trees were photographed using a digital photo camera of 8 mega pixels (EOS 350D, Canon), from the same position. Biotic damages in the crown were also recorded but there were so few that they have not been further taken into consideration.

Subsequently, according to the methodology suggested by Mizoue (2002), 7 trees with contrasted percentages of crown transparency were selected and photographed. Then the same crown images were analysed by one expert observer from the Spanish field crew of the European Level I network to provide an estimate of crown transparency.

A subset of 265 trees was also used to compare visual and digital crown transparency estimates. The 2695 trees were split into four groups corresponding to stand age and site condition combinations: 601 trees from "young and poor" stands, 609 from "young and rich", 847 from "adult and poor" and 638 from "adult and rich" stands respectively. Trees were sorted according to crown transparency values within each group and then one to ten trees were randomly selected within each crown transparency class in each of the four groups.

Values of DSO index of crown transparency were calculated using the CROCO method (Mizoue and Dobbertin, 2003). In CROCO an automatic thresholding algorithm is used to obtain crown silhouette images, where foliage and branches are transformed to black pixels and background sky to white pixels (Mizoue and Inoue, 2001). CROCO calculates two fractal dimensions to estimate the crown transparency of the tree silhouette (Ds) and outline (Do). DSO is calculated as the difference between Ds and Do indicating the index of crown transparency. DSO values decrease with increasing crown transparency. To implement this method we first cut out a rectangular region of interest (ROI) in each crown photograph, including the part of the crown exposed to the sunlight, but excluding the parts overlapping with adjacent trees. At the same time, the overlap rate (OR) was visually categorized into 8 classes (no overlap, 25, 50, 75, $100 \%$ overlap on one side of the crown and $25,50,75 \%$ overlap on both sides). Second, an automatic thresholding algorithm was applied to the blue-filtered grey scale image to generate a crown silhouette image. Finally, DSO values were calculated from the crown silhouette images using fractal analysis (Mizoue, 2001). Trees that overlapped have positively biased DSO values (underestimation of crown transparency). This was corrected using the simple linear regression model developed by Mizoue (2002). The corrected DSO provided an estimate of crown transparency, called Digital Crown Transparency (DCT). CROCO uses Scion Image for Windows (available for free at the http://www.scioncorp.com/) and image processing software (in this work we used Adobe Photoshop).

\subsection{Statistical analyses}

Paired $t$ tests of mean \% Visual Crown Transparency (VCT) and mean \% Visual Crown Discoloration (VCD) per stand were carried out to compare dependent variable mean values (after angular transformation, $\arcsin \sqrt{(x)}$, Peña, 2002) in the same stand but calculated from different sample sizes, i.e. combinations of one, two or three sub-plots per poplar stand. Only comparisons that did not involve the same sub-plot were tested to respect data independency. For the same reason the combination of four sub-plots was not tested as all other combinations would have had shared trees.

Analyses of variance (ANOVAs) and Tukey's HSD post-hoc test of VCT and VCD mean values per poplar stand from 4 sub-plots (2695 tree data) or 1 subplot (757 tree data) were carried out after angular transformation $(\arcsin \sqrt{(x)}$, Peña, 2002) to test whether the sample size used to calculate mean values can influence the detection of the effect of site quality, stand age and understorey management on both indicators.

Simple linear regressions were used to fit calibration curves of DCT against log VCT with data from 7 trees such as proposed by Mizoue (2002), and from 265 trees to test the fit with a higher number of trees. Finally, another ANOVA was carried out to check whether DCT would permit to detect the same effects of site quality, age and understorey management than VCT, using the dataset of 265 trees.

All analyses were performed using Statistica 6.0 package (StatSoft, 2001).

\section{RESULTS}

\subsection{Effect of sample size on crown conditions estimation in poplar stands}

Comparison of VCT and VCD mean values per stand $(N=$ 32) calculated from different combinations of one, two or three sub-plots did not show any significant differences (Tab. I), indicating that mean VCT and VCD values were similar when the sample size equalled ca. 21, 42 and 63 trees respectively.

Analyses of variance for VCT and VCD mean values per stand $(N=32)$, using trees from four subplots or from only one subplot, showed exactly the same significant effects of the factors on dependent variables (Tab. II). Visual crown transparency (VCT) and visual crown discoloration (VCD) mean values were similarly and significantly affected by site quality (Tab. II). Crown conditions were always of poorer quality (higher VCT and VCD values) in poor than in rich sites (Figs. 1 and 2). The interaction between site quality and stand age was significant for both VCT and VCD whereas the interaction between site quality and understorey management was only significant for mean visual crown transparency. This indicates that the pattern of crown conditions responded to both stand age and understorey management depending on site quality. Tukey's HSD tests (Figs. 1 and 2) revealed that in rich sites there was neither significant difference in VCT or VCD between old and young stands nor between harrowed or not harrowed stands. By contrast in poor sites, a significant increase of damage was observed in old stands (higher VCT and VCD values) as well as in harrowed stands (only for VCT). 
Table I. $P$ values of paired $t$ tests $(N=32)$ comparing means of \% Visual Crown Transparency or \% Visual Crown Discoloration (in italic) of poplar trees calculated with different combinations of one, two or three sub-plots per stand, after angular transformation $(\arcsin \sqrt{ }(x))$.

\begin{tabular}{|c|c|c|c|c|c|c|c|c|c|c|c|c|c|c|}
\hline & 1 & 2 & 3 & 4 & $1+2$ & $1+3$ & $1+4$ & $2+3$ & $2+4$ & $3+4$ & $1+2+3$ & $1+2+4$ & $1+3+4$ & $2+3+4$ \\
\hline 1 & & 0.964 & 0.549 & 0.978 & & & & 0.861 & 0.771 & 0.947 & & & & 0.906 \\
\hline 2 & 0.618 & & 0.373 & 0.941 & & 0.881 & 0.555 & & & 0.967 & & & 0.458 & \\
\hline 3 & 0.346 & 0.513 & & 0.452 & 0.250 & & 0.258 & & 0.185 & & & 0.141 & & \\
\hline 4 & 0.414 & 0.863 & 0.559 & & 0.773 & 0.982 & & 0.827 & & & 0.849 & & & \\
\hline $1+2$ & & & 0.335 & 0.488 & & & & & & 0.636 & & & & \\
\hline $1+3$ & & 0.996 & & 0.784 & & & & & 0.747 & & & & & \\
\hline $1+4$ & & 0.797 & 0.375 & & & & & 0.464 & & & & & & \\
\hline $2+3$ & 0.438 & & & 0.851 & & & 0.521 & & & & & & & \\
\hline $2+4$ & 0.505 & & 0.451 & & & 0.941 & & & & & & & & \\
\hline $3+4$ & 0.351 & 0.650 & & & 0.347 & & & & & & & & & \\
\hline $1+2+3$ & & & & 0.749 & & & & & & & & & & \\
\hline $1+2+4$ & & & 0.431 & & & & & & & & & & & \\
\hline $1+3+4$ & & 0.965 & & & & & & & & & & & & \\
\hline $2+3+4$ & 0.536 & & & & & & & & & & & & & \\
\hline
\end{tabular}

Numbers in lines and columns indicate sub-plot numbers and combinations. Light grey cells indicate inappropriate comparisons, those in which the two compared tree samples were not independent (i.e. sharing common trees).

Table II. Analyses of variance of Visual Crown Transparency and Visual Crown Discoloration mean values per poplar stand $(N=32)$ calculated from 4 sub-plots (2695 tree data) or 1 subplot (757 tree data) to test the effect of site quality, stand age and understorey management.

\begin{tabular}{|c|c|c|c|c|c|c|c|c|c|}
\hline \multirow{3}{*}{$\begin{array}{l}N=32 \\
\text { Source } \\
\end{array}$} & \multirow[b]{3}{*}{ d.f. } & \multicolumn{4}{|c|}{ Visual Crown Transparency } & \multicolumn{4}{|c|}{ Visual Crown Discoloration } \\
\hline & & \multicolumn{2}{|c|}{4 sub-plots } & \multicolumn{2}{|c|}{1 sub-plot } & \multicolumn{2}{|c|}{4 sub-plots } & \multicolumn{2}{|c|}{1 sub-plot } \\
\hline & & $F$ & $\operatorname{Pr}>F$ & $F$ & $\operatorname{Pr}>F$ & $F$ & $\operatorname{Pr}>F$ & $F$ & $\operatorname{Pr}>F$ \\
\hline Quality & 1 & 108.2 & $<0.01$ & 73.4 & $<0.01$ & 20.6 & $<0.01$ & 21.9 & $<0.01$ \\
\hline Management & 1 & 1.8 & 0.19 & 2.7 & 0.11 & 0.2 & 0.69 & 0.1 & 0.73 \\
\hline Age & 1 & 94.8 & $<\mathbf{0 . 0 1}$ & 50.2 & $<\mathbf{0 . 0 1}$ & 11.9 & $<0.01$ & 11.5 & $<0.01$ \\
\hline Quality $\times$ Management & 1 & 12.1 & $<\mathbf{0 . 0 1}$ & 7.2 & 0.01 & 0.7 & 0.41 & 1.2 & 0.28 \\
\hline Quality $\times$ Age & 1 & 46.2 & $<0.01$ & 30.8 & $<0.01$ & 10.9 & $<0.01$ & 8.9 & $<0.01$ \\
\hline Management $\times$ Age & 1 & $<0.1$ & 0.99 & $<0.1$ & 0.98 & $<0.1$ & 0.87 & $<0.1$ & 0.77 \\
\hline Quality $\times$ Management $\times$ Age & 1 & 0.3 & 0.62 & $<0.1$ & 0.85 & 0.1 & 0.78 & 0.2 & 0.66 \\
\hline
\end{tabular}

\subsection{Ability of CROCO to replace visual crown transparency assessment}

Based on a sample of seven trees selected along a linear gradient of crown transparency, the calibration curve between visual estimates (log VCT values) and digital estimates (DCT values obtained with $\mathrm{CROCO}$ ) showed a very good fit with a simple regression $\left(R^{2}=0.97, P<0.0001\right)$ (Fig. 3). Similar regression, made with data from 265 trees selected across a longer gradient of VCT values, showed a good fit too $\left(\mathrm{R}^{2}=\right.$ 0.64, $P<0.0001$ ) (Fig. 4).

Analyses of variance for VCT and DCT mean values per stand $(N=32)$, using the subset of 265 trees, showed similar effects of the factors, although slightly less significant for the Digital Crown Transparency dependant variable (Tab. III). Furthermore the significant effects of factors and of interactions between factors were consistent with those obtained when mean values were calculated from all trees (Tab. II). The only discrepancy concerns the moderate significant effect of understorey management on mean VCT calculated with 265 trees (Tab. III).

\section{DISCUSSION}

Several studies have analysed the effect of different factors, such as stand age and site conditions on crown condition in trees (Bussotti et al., 2002; Hendriks et al., 2000; Innes, 1993; Klap et al., 2000; Solberg, 1999). Stand age has often been considered as a factor potentially affecting crown transparency. Hendriks et al. (2000) observed that crown transparency significantly increased with tree age in oak and Scots pine but not in Douglas fir. In the present study crown transparency was higher in older clonal poplar plantations, particularly in poor sites. The elongation of branches in older trees may have given the impression that crown is more transparent (Metzger and Oren, 2001). The susceptibility of trees to biotic agents may also increase with age (Solberg, 1999), as well as stress factors such as drought or nutritional deficiency thus resulting in a cumulative detrimental effect with age. In this study results also showed that crown conditions in poplar stands improved with site quality, which is corroborated by several authors (Ferretti, 1998; Solberg, 1999). It is likely that nutritional stress in poor quality sites had a detrimental effect 


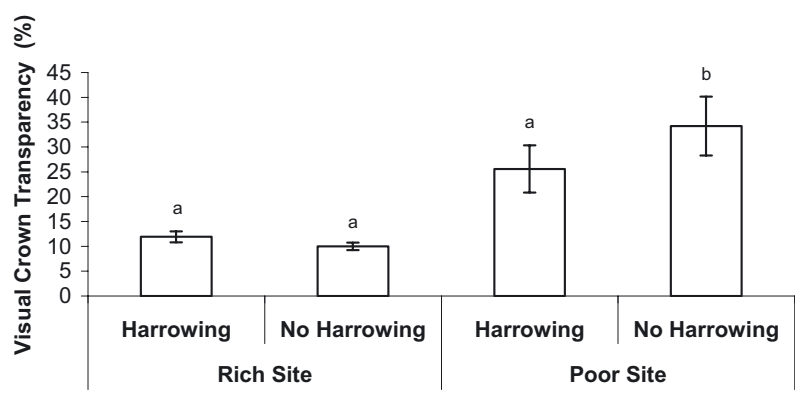

(a)

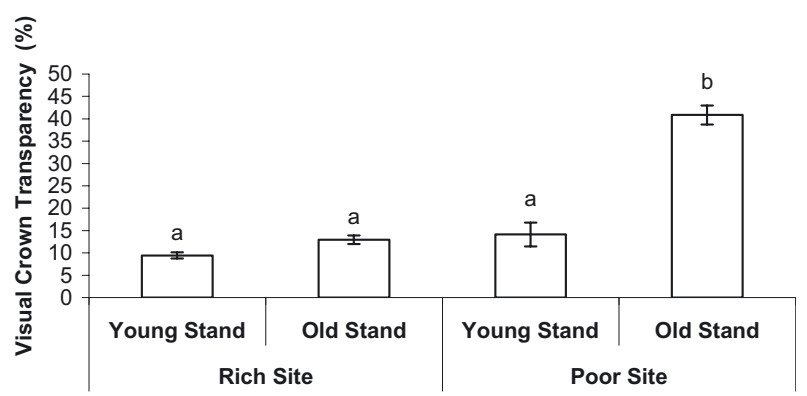

(b)

Figure 1. Mean ( \pm S.E.) Visual Crown Transparency (VCT) values per poplar stand for each site quality type according to (a) understorey management and (b) stand age. Within each site quality, bars with different letters indicate significantly different means (Tukey's posthoc test, $\alpha=0.05$ ).

on tree physiology, resulting in a proportional reduction of foliar biomass or increased the susceptibility of trees to biotic hazards that damaged tree crowns. To our knowledge, the effect of forest management on crown conditions had never been studied in poplars. Our results showed that harrowing understorey vegetation, the main management practice in poplar plantations, had a beneficial effect on crown conditions in poor sites. Harrowing may reduce competition between understorey vegetation and trees for water and nutrient supply. Furthermore harrowing may also improve the soil structure and facilitate the incorporation of nutrients into the litter, thus resulting in a gain of stand fertility. These advantages should be more important in poor sites because competition for water and nutrient is higher. Crown discoloration seems to respond in the same manner to the same stand factors although slightly less significantly. This may result from less accurate VCD estimates since crown discoloration is known to be more difficult to be assessed objectively (Ferretti, 1998; Wulff, 2002).

Different shapes and sizes of sampled plot have been proposed for forest health surveys, like four subplots of six trees located $25 \mathrm{~m}$ from a fixed point by the ICP-Forest in Europe (Eichhorn et al., 2006), four subplots spaced $36.6 \mathrm{~m}$ apart with a fixed radius by the Forest Health Monitoring in the U.S. (Zarnoch et al., 2004) and one circular plot of 24 trees in Spain (SPCAN-DGCN, 2002). In this study there was no significant difference between the mean values of crown condition variables calculated from one, two or three subplots of

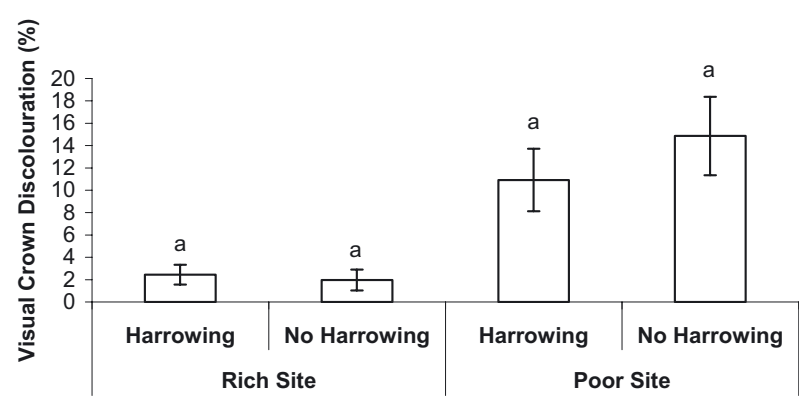

(a)

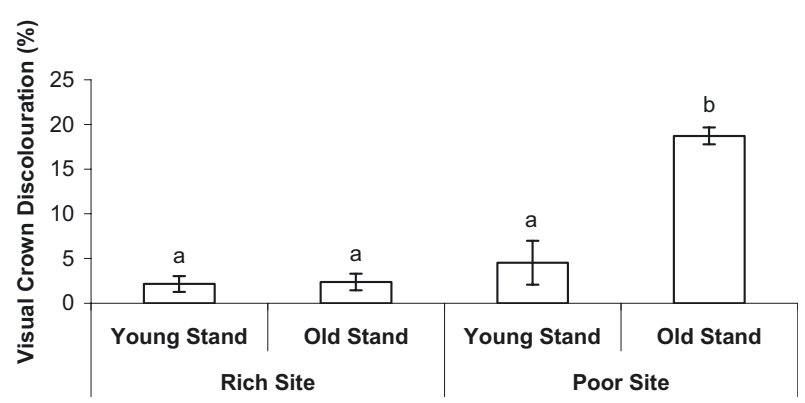

(b)

Figure 2. Mean ( \pm S.E.) Visual Crown Discoloration (VCD) values per poplar stand for each site quality type according to (a) understorey management and (b) stand age. Within each site quality, bars with different letters indicate significantly different means (Tukey's posthoc test, $\alpha=0.05$ ).

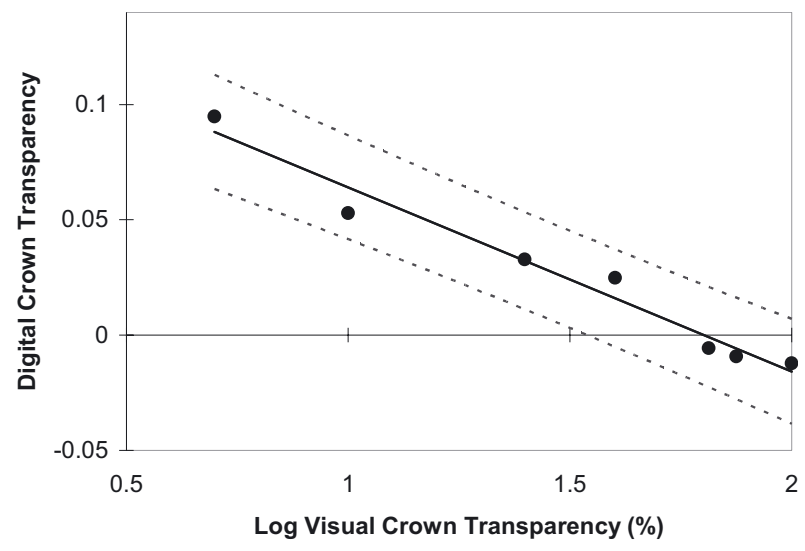

Figure 3. Relationship between Visual and Digital Crown Transparency values obtained with the CROCO computation in 7 poplar trees of contrasted crown transparency. Continuous line indicates the regression fit; dotted line indicates the confidence interval $(95 \%)$ $\left(N=7, F_{6,1}=152.0, P<0.0001, R^{2}=0.97\right)$.

$15 \mathrm{~m}$ radius. Moreover, mean values calculated from only one subplot of ca. 21 trees could be used to discriminate the same effect of driving factors than those computed from four subplots. Contrary to the results obtained by Innes and Boswell (1990) in even-aged stands of conifers, who demonstrated significant variations amongst the 4 subplots of each plot, the assessment of only one subplot of fixed radius (exactly $15 \mathrm{~m}$, 


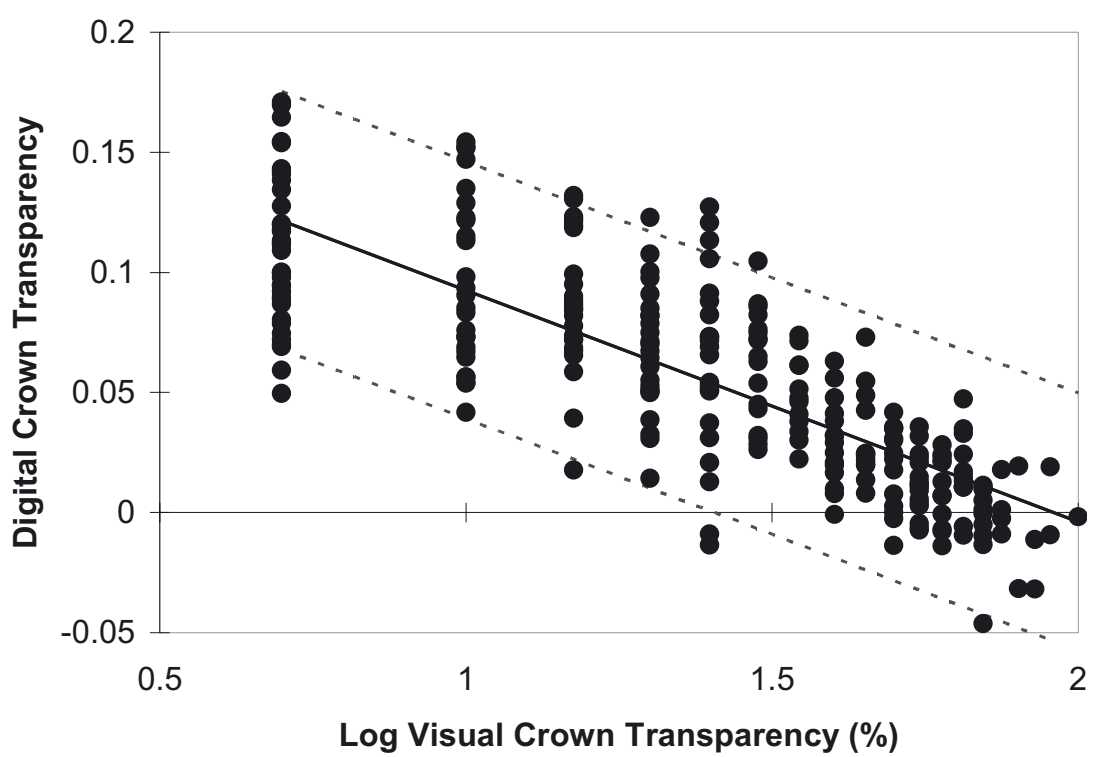

Figure 4. Relationship between Visual and Digital Crown Transparency values obtained with the CROCO computation in 265 poplar trees of contrasted crown transparency. Continuous line indicates the regression fit; dotted line indicates the confidence interval $(95 \%)(N=265$, $\left.F_{264,1}=467.0, P<0.0001, R^{2}=0.64\right)$.

Table III. Analyses of variance of Visual and Digital Crown Transparency mean values per poplar stand $(N=32)$ calculated with 265 trees data to test the effect of site quality, stand age and understorey management.

\begin{tabular}{lccccc}
\hline$N=32$ & & \multicolumn{3}{c}{ Crown Transparency } \\
\cline { 2 - 6 } & & \multicolumn{2}{c}{ Visual } & \multicolumn{2}{c}{ Digital } \\
\hline Source & $d . f$. & $F$ & $\operatorname{Pr}>F$ & $F$ & $\operatorname{Pr}>F$ \\
Quality & 1 & 75.1 & $<\mathbf{0 . 0 1}$ & 25.7 & $<\mathbf{0 . 0 1}$ \\
Management & 1 & 7.2 & $\mathbf{0 . 0 1}$ & 0.3 & 0.61 \\
Age & 1 & 43.4 & $<\mathbf{0 . 0 1}$ & 7.4 & $\mathbf{0 . 0 1}$ \\
Quality $\times$ Management & 1 & 16.5 & $<\mathbf{0 . 0 1}$ & 4.9 & $\mathbf{0 . 0 4}$ \\
Quality $\times$ Age & 1 & 33.9 & $<\mathbf{0 . 0 1}$ & 11.9 & $<\mathbf{0 . 0 1}$ \\
Management $\times$ Age & 1 & $<0.1$ & 0.87 & 0.9 & 0.3 \\
Quality $\times$ Management $\times$ Age & 1 & 3.6 & 0.07 & 1.3 & 0.3 \\
\hline
\end{tabular}

i.e. approximately 18 trees in plantations with planting distance $6 \times 6 \mathrm{~m}$ ) seems to be sufficient to qualify forest health in poplar plantation. This discrepancy may be due to the higher homogeneity of trees within monoclonal plantations.

Because crown transparency can be considered as a relevant indicator to assess tree crown condition in poplars, our next aim was to tune up a methodology to estimate it objectively. We used the CROCO methodology developed by Mizoue (2002) and with a sample of 7 trees of contrasted crown conditions, we obtained a highly significant correlation between visual and digital crown transparency estimates $\left(R^{2}=96.18 \%\right)$. This value was comparable to those obtained with a similar approach in Norway spruce, silver fir, Scots pine, larch, beech, pedunculate oak, sycamore and ash, for which $R^{2}$ varied between 93 and 99\% (Mizoue and Dobbertin, 2004).
We could also successfully fit a significant linear model relating visual and digital crown transparency estimates in a larger sample of 265 poplar trees, indicating that operational calibration curves, with more reference points across a longer range of VCT values, could be delivered to end-users. The use of trees from a single clone (I-214) probably made this result possible (Al Afas et al., 2007). Moreover, we demonstrated that DCT values were accurate enough to allow detecting the driving factors of crown transparency in poplar stands.

We therefore believe that the CROCO method is a valuable tool to precisely assess the "crown transparency" indicator in poplar plantation. Problems due to the subjectivity of visual assessment may be then solved, thus facilitating the investigation of biotic agents or abiotic factors responsible for changes in crown transparency (Hendriks et al., 2000) and allowing comparison between surveys results over time (Mizoue and Dobbertin, 2003). It is possible that in the future, national forest inventories have to record more variables than the traditional dendrometric features, for example tree health status. In this context, we have shown that the CROCO methodology is particularly relevant to crown transparency monitoring in poplar stands because it can be used with small tree sample size, such as one fixed $15 \mathrm{~m}$-radius plot, and because it can be applied with no special expertise in tree pathology.

Acknowledgements: We are grateful to Dr. Mizoue of Miyazaki University, Japan, for providing free the software CROCO and for valuable suggestions. We thank Oscar Osorno for scoring the crown transparency in the photographs used in the fit. The authors also thank Ana Pérez Sierra for her helpful comments on the last version of the manuscript. Financial support of this study was provided by European Union and Regional Government of Castilla y León, through the INTERREG IIIB program Atlantic Area (FORSEE project). 


\section{REFERENCES}

Al Afas N., Marron N., and Ceulemans R., 2007. Variability in Populus leaf anatomy and morphology in relation to Canopo position, biomass production, and varietal taxon. Ann. For. Sci. 64: 521-532.

Braganca M., DeSouza O., and Zanuncio J.C., 1998. Environmental heterogeneity as a strategy for pest management in Eucalyptus plantations. For. Ecol. Manage. 102: 9-12.

Bravo F., Grau J.M., and Antoñanzas F.G., 1995. Curvas de calidad y tablas de producción para Populus x euramericana en la cuenca del Duero. Montes 44: 43-46.

Bussotti F., Cozzi A., Ferretti M., Cenni E., Bettini D., and Nibbi R., 2002. Crown condition assessment at the CONECOFOR permanent monitoring plots. J. Limnol. 61: 12-18.

Camps F., 2001. Principales plagas y enfermedades de chopo. I Simposio del chopo, Zamora, Junta de Castilla y León.

Castañeda F., Palmberg-Lerche C., and Vuorinen P., 2001. Criteria and indicators for sustainable forest management: A compendium. Forest management working papers, Working paper 5, Forest Resources Development Service, Forest Resources Division. FAO, Rome.

Čermák J., Gašpárek J., De Lorenzi F., and Jones H., 2007. Stand biometry and leaf area distribution in an old olive grove at Andrea, southern Italy. Ann. For. Sci. 64: 491-501.

Coops N.C., Stone C., Culvenor D.S., and Chisholm S., 2004. Assessment of crown condition in eucalypt vegetation by remotely sensed optical indices. J. Environ. Qual. 33: 956-64.

Eichhorn J., Szepesi A., Ferretti M., Durrant D., and Roskams P., 2006. Part II: Visual assessment of tree condition. In: Manual on methods and criteria for harmonized sampling, assessment, monitoring and analysis of the effects of air pollution on forests, United Nations Economics Commision for Europe, International Cooperative Programme on Assessment and Monitoring of Air Pollution Effects on Forests (ICP-Forests).

Fernández A. and Hernanz G., 2004. El chopo (Populus sp.) Manual de Gestión Forestal Sostenible, Junta de Castilla y León, 53 p.

Ferretti M., 1997. Forest health assessment and monitoring - Issues for consideration. Environ. Monit. Assess. 48: 45-72.

Ferretti M., 1998. Potential and limitation of visual indices of tree condition. Chemosphere 36: 1031-1036.

Frampton C.M., Pekelharing C.J., and Payton I.J., 2001. A fast method for monitoring foliage density in single lower-canopy trees. Environ. Monit. Assess. 72: 227-34.

Ghosh S. and Innes J.L., 1995. Combining field and control team assessments to obtain error-estimates for surveys of crown condition. Scand. J. For. Res. 10: 264-270.

Ghosh S., Innes J.L., and Hoffmann C., 1995. Observer variation as a source of error in assessments of crown condition through time. For. Sci. 41: 235-254.

Hendriks C.M.A., Olsthoorn A.F.M., Klap J.M., Goedhart P.W., Oude Voshaar J.H., Bleeker A., De Vries F., Van Der Salm C., Voogd J.H.C., De Vries W., and Wijdeven S.M.J., 2000. Relationships between crown condition and its determining factors in The Netherlands for the period 1984 to 1994. Wageningen, Alterra, Green World Research, $70 \mathrm{p}$.

Hunsaker C.T., 1993. New concepts in environmental monitoring: the question of indicators. The science of total environment. Supplement, pp. 77-95.

Innes J.L., 1993. Some factors affecting the crown condition density of trees in Great Britain based in recent annual surveys of forest condition. Forest decline in the Atlantic and Pacific region. Huettl/MuellerDombois, Springer-Verlag Berlin Heidelberg, pp. 40-53.

Innes J.L. and Boswell R.C., 1990. Reliability, presentation, and relationships among data from inventories of forest condition. Can. J. For. Res./Rev. Can. Rech. For. 20: 790-799.
Innes J.L., Landmann G., and Mettendorf B., 1993. Consistency of Observations of Forest Tree Defoliation in 3 European Countries. Environ. Monitor. Assess. 25: 29-40.

Klap J.M., Voshaar J.H.O., De Vries W., and Erisman J.W., 2000. Effects of environmental stress on forest crown condition in Europe. Part IV: Statistical analysis of relationships. Water, Air, Soil Pollut. 119: 387-420.

Lorenz M., Becher G., Mues W., Fisher R., Becker R., Calatayud V., Dise N., Krause G.H.M., Sanz M., and Ulrich E., 2005. Forest condition in Europe, report of the 2004 survey. Geneva, UN/ECE, CEC, 99 p.

Metzger J.M. and Oren R., 2001. The effect of crown dimensions on transparency and the assessment of tree health. Ecol. Appl. 11: $1634-1640$.

Mizoue N., 2001. Fractal analysis of tree crown images in relation to crown transparency. J. For. Plann. 7: 79-87.

Mizoue N., 2002. CROCO: Semi-automatic image analysis system for crown condition assessment in forest health monitoring. J. For. Plann. 8: $17-24$.

Mizoue N. and Dobbertin M., 2003. Detecting differences in crown transparency assessments between countries using the image analysis system CROCO. Environ. Monitor. Assess. 89: 179-195.

Mizoue N. and Dobbertin M., 2004. Within country accuracy of tree crown transparency estimates using the image analysis system CROCO: a case study from Switzerland. Environ. Model. Software 19: 1089-1095.

Mizoue N. and Inoue A., 2001. Automatic thresholding of tree crown images. J. For. Plann. 6: 75-80.

Peña D., 2002. Regresión y diseño de experimentos. Alianza, Madrid, $744 \mathrm{p}$.

Redfern D.B. and Boswell R.C., 2004. Assessment of crown condition in forest trees: comparison of methods, sources of variation and observer bias. For. Ecol. Manage. 188: 149-160.

Sang-Mook L., Clark N., and Araman P., 2003. Automated methods of tree boundary extraction and foliage transparency estimation from digital imagery. 19th Biennal Workshop on Color Photography and Videography in Resource Assessment, Logan, Utah.

Sierra J.M., 2001. Plagas y enfermedades de los chopos en España, con especial referencia a Castilla y León. I Simposio del chopo, Zamora, Junta de Castilla y León.

Solberg S., 1999. Crown density changes of Norway spruce and the influence from increased age on permanent monitoring plots in Norway during 1988-1997. Eur. J. For. Pathol. 29: 219-230.

Solberg S. and Strand L., 1999. Crown density assessments, control surveys and reproducibility. Environ. Monitor. Assess. 56: 75-86.

Solberg S., Naesset E., Lange H., and Bollandsas O.M., 2004. Remote sensing of forest health. Natcan International Conference on LaserScanners for Forest and Landscape Assessment, Freiburg.

SPCAN-DGCN, 2002. Red de seguimiento de daños en los montes (Red CE de nivel I). Manual de campo, Ministerio de Medio Ambiente, $55 \mathrm{p}$.

StafSoft I., 2001. STATISTICA (data analysis software system), version 6.0. www.statsoft.com.

Stone C., Wardlaw R.F., Carnegie A., Wyllie R., and De Little D., 2003. Harmonization of methods for the assessment and reporting of forest health in Australia - a starting point. Aust. For. 66: 233-246.

Wulff S., 2002. The accuracy of forest damage assessments - Experiences from Sweden. Environ. Monitor. Assess. 74: 295-309.

Zarnoch S.J., Bechtold W.A., and Stolte K.W., 2004. Using crown condition variables as indicators of forest health. Can. J. For. Res./Rev. Can. Rech. For. 34: 1057-1070. 